\title{
Jurnal Pendidikan Teknik Sipil
}

Volume 8, No 1, Februari 2019

Tersedia Online: http://journal.unj.ac.id/unj/index.php/ipensil

\section{PENGEMBANGAN MEDIA PEMBELAJARAN BERBASIS KOMIK PADA KONSTRUKSI BANGUNAN 1}

\author{
(Studi Kasus UNJ Jurusan pendidikan Vokasional Bangunan)
}

\author{
Neneng Rafika Ayu', Riyan Arthur', Amos Neolaka ${ }^{3}$ \\ 1,2,3 Universitas Negeri Jakarta \\ 1rafikaayu10@gmail.com, 2arthur@unj.ac.id,3a.neolaka@unj.ac.id \\ Diterima : 6 Februari 2019 \\ Direvisi : 20 Februari 2019 \\ Diterbitkan : 28 Februari 2019 \\ DOI $\quad:$ http://doi.org/10.21009/ ipensil.v8i1.10628
}

\begin{abstract}
The purpose of this research is to develop learning specifically on digital comic media, State University of Jakarta. The rmethod non-test research instruments in the form of student needs analysis questionnaires, feasibility questionnaires to media experts and material experts as well as test questionnaires to lecturers and students or questionnaires. Then at the stage of research and information gathering a needs analysis survey was conducted of students and students about the development of comic learning media to determine the needs and constraints faced by students. The results of the assessment in the form of digital comic product designs amounted to $90 \%$ (very good). The number of final average aspects and indicators of the characteristics of learning media amounted to $91.3 \%$ (very good / decent). The assessment of the material presented in digital comics media is considered good with results reaching $73 \%$. The results of the product feasibility assessment assessed by 20 students from the Building Engineering Education Study Program were obtained at 91\% (very good). Then the material validation and media on digital comic products developed were obtained an average score of $82.33 \%$ and included in the excellent category. Therefore the product can be said to be feasible to use.
\end{abstract}

Keywords: Learning Media, Digital Comics, Building Construction.

\section{Pendahuluan}

Penerapan media pembelajaran dalam proses belajar-mengajar memang sudah tidak asing lagi dalam rangka meningkatkan proses dan hasil belajar pada bidang pendidikan. Media pembelajaran dewasa ini sudah banyak diterapkan oleh para pendidik di dalam proses pengajaran materi pada peserta didik di berbagai lembaga atau institusi kependidikan. Di samping itu pula, penerapan pengajaran berbasis media mampu memberikan pengaruh positif bagi peserta didik dalam proses belajar dan meningkatkan mutu atau kualitas pembelajaran, serta demi tercapainya tujuan pembelajaran seperti yang diharapkan.

Pada buku Arsyad (2010,p.15), Hamalik mengemukakan bahwa pemakaian media pembelajaran dalam proses belajar mengajar dapat membangkitkan keinginan dan minat yang baru, membangkitkan motivasi dan rangsangan kegiatan belajar, bahkan membawa pengaruh-pengaruh psikologis terhadap siswa.

Demikian pula, Sudjana dan Rivai (2010: 2) mengemukakan manfaat media dalam proses belajar siswa, yaitu pembelajaran akan lebih menarik perhatian 
siswa sehingga menumbuhkan motivasi belajar, bahan pembelajaran akan lebih mudah dipahami oleh siswa, metode mengajar akan lebih bervariasi, dan siswa dapat banyak melakukan kegiatan belajar sebab tidak hanya mendengarkan uraian guru, tetapi juga bisa mengamati, mendemontrasikan, memerankan, dan sebagainya.

Berdasarkan hasil analisis kebutuhan yang dilakukan pada 50 mahasiswa program studi Pendidikan Teknik Bangunan, Universitas Negeri Jakarta, dapat disimpulkan dengan hasil persentase yang diperoleh bahwa 96,6\% mahasiswa menyatakan membutuhkan media pembelajaran selain slide dan buku teks dalam mata kuliah konstruksi bangunan 1 serta 79,3\% mahasiswa menjawab dosen kurang menggunakan media yang bervariasi. Hal tersebut dinyatakan dengan 96,6\% mahasiswa tertarik apabila pembelajaran Konstruksi bangunan 1 dikemas dalam bentuk media komik sebagai media pembelajaran.

Menurut Listiyani (2012: 3) mengemukakan telah dikembangkan berbagai macam media yang bersifat visual. Pengembangan ini mendukung potensi peserta didik secara umum yang secara alami dalam belajar lebih banyak menggunakan indra penglihatan yaitu mata. Selain penekanan pada sisi visual, media yang lebih didukung untuk dikembangkan adalah media yang mendukung pembelajaran yang menyenangkan. Hal ini dimaksudkan agar peserta didik mau mengikuti pembelajaran dengan antusias, sehingga mata pelajaran yang dipelajari akan lebih mudah terekam pada memori peserta didik.

Selaras dengan hal itu, pihak instusi pendidikan dituntut untuk bisa memberikan penyajian system pembelajaran yang sesuai dengan karakter peserta didik sebagai generasi milenial. Generasi milenial memiliki karakter yang aktif dalam mencari informasi. Hal tersebut tidak lain mereka dapati dengan cara browsing internet, mengingat internet merupakan hal yang sudah menjadi ketergantungan bagi generasi ini. Selain itu, generasi ini juga lebih menyukai informasi yang disajikan dalam bentuk visual dibanding tekstual atau ceramah.

Berdasarkan pemaparan di atas, penulis tertarik untuk mencoba sebuah media pembelajaran baru sehingga materi perkuliahan konstruksi bangunan lebih dapat dipahami dan diaplikasikan secara maksimal oleh mahasiswa Prodi Pendidikan Teknik Bangunan, Universitas Negeri Jakarta, yakni dengan media pembelajaran komik digital sehingga komik yang menarik ini dapat di akses kapan saja dan dimana saja. Penelitian ini akan membahas soal efektivitas pembelajaran melalui komik digital tersebut terhadap pemahaman dan kesadaran mahasiswa pada materi kuliah konstruksi bangunan.

Pada penelitian terdahulu terkait media pembelajaran, Setyorini (2017: 5) menyimpulkan jika komik digital efektif untuk mengajar monolog para siswa visual maupun auditori, dan komik digital lebih efektif jika dibandingkan dengan komik cetak. Diperkuat dengan pernyataan Marianthi (2015: 3) bahwa untuk pengajaran masa depan tampaknya komik memiliki nilai yang jelas sebagai alat yang inovatif.

Mata kuliah konstruksi bangunan 1 dipilih karena mata kuliah tersebut adalah mata kuliah dasar yang akan menjadi lanjutan dari mata kuliah selanjutnya. Mata kuliah konstruksi bangunan 1 mendeskripikan tentang struktur bangunan, sambungan kayu, atap, dan lain lain. Materi konstruksi bangunan 1 akan berfokus pada gambar-gambar yang nantinya akan bermanfaat untuk mahasiswa saat menjalani masa PKL. Melalui media pembelajaran komik pada mata kuliah konstruksi bangunan 1 pemahaman mahasiswa akan semakin meningkat dan pemahaman tersebut dapat menjadi bekal ilmu untuk mata kuliah selanjutnya. 
Maka dari itu penelitian ini bertujuan untuk mengembangkan media pembelajaran komik digital pada Kompetensi Dasar Konstruksi Bangunan I pada mata kuliah konstruksi bangunan I Program studi Pendidikan Teknik Bangunan, Fakultas Teknik, Universitas Negeri Jakarta.

\section{Metode Penelitian}

Jenis penelitian ini adalah penelitian dan pengembangan (Research and development) Pengumpulan data dan informasi berupa data yang diperoleh dari instrument berupa data kualitatif dan kuantiatif. Metode pengumpulan data yang dilakukan oleh peneliti adalah kuesionar (angket). Kuesioner ini bertujuan untuk mengetahui tingkat kelayakan produk dari aspek materi dan aspek media, serta untuk mengetahui penilaian dari mahasiswa. Memvalidasi instrumen dengan likert dan aiken. Tempat penelitian di Program studi Pendidikan Teknik Bangunan. Waktu penelitian untuk media pembelajaran Konstruksi Bangunan 1 dilaksanakan pada semester 109.

\section{Hasil Penelitian dan Pembahasan}

Penelitian ini merupakan jenis penelitian pengembangan dengan menggunakan metode penelitian research and development $(\mathrm{R} \& \mathrm{D})$ yang mana peneliti mengembangkan sebuah produk berupa media komik sebagai media pembeljaran pada mata kuliah konstruksi bangunan. Adapun tujuan dari pengembangan produk media pembelajaran ini adalah untuk mengenalkan variasi media yang lebih inovatif dan menarik kepada pendidik dan peserta didik. Selain itu juga, penelitian ini akan menjelaskan tingkat kelayakan serta keefektivitasan produk komik digital tersebut.

Adapun prosedur penerapan media pembelajaran komik digital didasari dari skenario atau strategi pembelajaran digunakan sebagai acuan untuk menerapkan media komik digital sebagai media pembelajaran di dalam kelas. Berikut skenario pembelajaran:

Tabel 1. Skenario Pembelajaran Mahasiswa Vokasional Konstruksi Bangunan

\begin{tabular}{|c|c|c|}
\hline \multicolumn{3}{|c|}{ SKENARIO PEMBELAJARAN } \\
\hline \multicolumn{2}{|c|}{ PENDAHULUAN } & Waktu \\
\hline DOSEN & MAHASISWA & \multirow{2}{*}{$15 \mathrm{~m}$} \\
\hline $\begin{array}{r}\text { Dosen masuk kedalam } 1 \\
\text { mahasiswa uı }\end{array}$ & $\begin{array}{l}\text { as dan menyiapkan } \\
\mathrm{k} \text { belajar }\end{array}$ & \\
\hline \multicolumn{2}{|c|}{ INTI } & Waktu \\
\hline DOSEN & MAHASISWA & \multirow{5}{*}{$290 \mathrm{~m}$} \\
\hline $\begin{array}{c}\text { Meminta mahasiswa } \\
\text { membaca dan memahami } \\
\text { materi pada komik di } \\
\text { episode yang telah } \\
\text { ditentukan } \\
\end{array}$ & $\begin{array}{l}\text { Membaca dan } \\
\text { memahami materi } \\
\text { episode komik yang } \\
\text { diminta dosen }\end{array}$ & \\
\hline $\begin{array}{c}\text { Menanyakan kepada } \\
\text { mahasiswa inti materi yang } \\
\text { dibahas di komik }\end{array}$ & $\begin{array}{c}\text { Menjawab pertanyaan } \\
\text { dosen }\end{array}$ & \\
\hline $\begin{array}{c}\text { Meminta mahasiswa } \\
\text { membuat kelompok 1-3 } \\
\text { orang } \\
\end{array}$ & $\begin{array}{l}\text { Membuat kelompok 1- } \\
3 \text { orang }\end{array}$ & \\
\hline $\begin{array}{l}\text { Memberikan beberapa } \\
\text { pertanyaan berkenaan } \\
\text { tentang materi di komik }\end{array}$ & $\begin{array}{l}\text { Mendiskusikan } \\
\text { pertanyaan secara } \\
\text { berkelompok }\end{array}$ & \\
\hline \multicolumn{2}{|c|}{ INTI } & \multirow{8}{*}{$290 \mathrm{~m}$} \\
\hline DOSEN & MAHASISWA & \\
\hline $\begin{array}{c}\text { Perbolehkan mahasiswa } \\
\text { membaca lagi materi yang } \\
\text { ada di komik } \\
\end{array}$ & $\begin{array}{c}\text { Mahasiswa membaca } \\
\text { lagi materi yang ada di } \\
\text { komik }\end{array}$ & \\
\hline $\begin{array}{c}\text { Perbolehkan membuka } \\
\text { internet bersumber arahan } \\
\text { materi di komik } \\
\end{array}$ & $\begin{array}{c}\text { Membuka internet } \\
\text { bersumber arahan } \\
\text { materi di komik }\end{array}$ & \\
\hline $\begin{array}{c}\text { Meminta mahasiswa } \\
\text { menggali informasi tentang } \\
\text { materi yang ada }\end{array}$ & $\begin{array}{c}\text { Menulis hasil diskusi \& } \\
\text { informasi yang sudah } \\
\text { didapat }\end{array}$ & \\
\hline $\begin{array}{c}\text { Meminta mahasiswa untuk } \\
\text { mempresentasikan hasil } \\
\text { diskusi }\end{array}$ & $\begin{array}{l}\text { Mempresentasikan } \\
\text { hasil diskusi }\end{array}$ & \\
\hline $\begin{array}{c}\text { Meminta kelompok lain } \\
\text { memberi } \\
\text { tanggapan/pertanyaan }\end{array}$ & $\begin{array}{c}\text { Menerima tanggapan } \\
\text { dari mahasiswa dan } \\
\text { kelompok lain } \\
\end{array}$ & \\
\hline $\begin{array}{l}\text { Meminta kesimpulan materi } \\
\text { yang telah didiskusikan dari } \\
\text { mahasiswa }\end{array}$ & $\begin{array}{c}\text { Menyimpulkan } \\
\text { kesimpulan yang } \\
\text { dipahami mahasiswa } \\
\end{array}$ & \\
\hline \multicolumn{3}{|c|}{ PENUTUP } \\
\hline $\begin{array}{c}\text { Menyimpulkan materi } \\
\text { pelajaran yang sudah } \\
\text { dibahas }\end{array}$ & $\begin{array}{c}\text { Mendengarkan } \\
\text { kesimpulan dosen }\end{array}$ & \multirow{5}{*}{$10 \mathrm{~m}$} \\
\hline $\begin{array}{l}\text { Memberikan tugas untuk } \\
\text { pertemuan selanjutnya }\end{array}$ & $\begin{array}{c}\text { Mencatat tugas yang } \\
\text { diberikan }\end{array}$ & \\
\hline $\begin{array}{l}\text { Memberikan gambaran } \\
\text { materi episode berikutnya }\end{array}$ & $\begin{array}{c}\text { Memahami pernyataan } \\
\text { dosen }\end{array}$ & \\
\hline $\begin{array}{c}\text { Mengarahkan mahasiswa } \\
\text { untuk berdoa dan menutup } \\
\text { pembelajaran } \\
\end{array}$ & $\begin{array}{l}\text { Berdoa dan menutup } \\
\text { pembelajaran }\end{array}$ & \\
\hline Mengucapkan salam & Menjawab salam & \\
\hline
\end{tabular}

Pengembangan media pembelajaran pada mata kuliah konstruksi bangun ini didesain dan diproduksi menjadi sebuah 
produk berupa media komik digital, tujuannya untuk memudahkan peserta didik (mahasiswa) dalam memahami materi konstruksi bangun I. Pada penggunaan media komik digital ini dosen menjadi fasilitator dalam pembelajaran sedangkan mahasiswa berperan aktif dalam pembelajaran melalui diskusi.

Data hasil validasi desain produk media komik digital pada materi konstruksi bangunan I dinilai 'sangat baik' atau 'sangat layak' untuk dijadikan sebagai media pembelajaran. Hal tersebut dapat dilihat dari rerata nilai dari tujuh indikator berupa 1) kesesuaian layout pada tampilan komik digital, 2) tek di dalam media komik digital juga jelas terbaca, 3) memiliki daya tarik ilustrasi yang menarik, 4) gambar komik dengan materi pembelajaran pun dinilai sesuai, 5) pengguna komik digital lebih mudah menggunakan navigasinya, 6) tidak hanya berupa penjelasan materi konstruksi bangun I namun juga di dalmnya terdapat latiha soal evaluasi, 7) media komik digital ini mampu dijadikan sebagai pelengkap pembelajaran materi konstruksi bangun, sehingga jika dirata-rata penilaian desain produk komik digital berjumlah 90\% yang masuk dalam rentan $81-100 \%$ dan dinilai 'sangat baik'.

Berdasarkan data hasil validasi oleh ahli media dinyatakan bahwa dalam aspek (1) teks $87 \%$ dinyatakan sangat baik, aspek (2) gambar 98\% dinyatakan sangat baik, (3) tampilan 90\% dinyatakan sangat baik, (4) fungsi $90 \%$ dinyatakan sangat baik, dan (5) manfaat $87 \%$ dinyatakan sangat baik. Selanjutnya, masing-masing aspek dan indikator dirata-rata. Adapun jumlah ratarata akhir aspek dan indikator validasi ahli media berjumlah 91,3\% (91\%), yang artinya bahwa media komik digital ini berada pada rerata $81-100 \%$ yang masuk pada klasifikasi sangat baik atau layak dan tidak perlu direvisi.

Kemudian Berdasarkan hasil analisis validitas isi (content validity) dari Aiken's V untuk ahli media menghasilkan nilai diatas 0,5, maka dari itu seluruh indikator hasil validasi Aiken's $\mathrm{V}$ ahli media memiliki nilai validitas yang memadai.

Selanjutnya berdasarkan data hasil validasi oleh ahli materi, media komik digital dinilai 'baik' terlihat hasil akhir antara aspek materi dan media memiliki hasil akhir $73 \%$ yang mana masuk pada klasifikasi baik. Adapun penjelasan dari 5 ahli yaitu 3 ahli materi pembelajaran yakni: (Drs Santoso Sri Handoyo, MT, Drs Doddy Rochadi, Dra Rosmawita Saleh, M.Pd) dan 2 Ahli Media pembelajaran yakni: ( RA Murti Kusuma W.S.IP, M.Si, dan Cecep Kustandi, M.Pd ) masingmasing indikator pada aspek materi yaitu 1) kesesuaian materi dengan kompetensi dinilai "sangat baik", 2) ketepatan dan keakuratan materi dinilai "baik", 3) kesesuain cerita dengan materi dinilai "baik", 4) kejelasan materi dinilai "baik", 5) kedalaman materi dinilai "baik", 6) kesukaran materi dinilai "baik", 7) kebenaran konsep dinilai "baik", 8) terdapat soal dan evaluasi yang menambah nilai "baik" dari media komik digital ini. Selanjutnya aspek media pembelajaran juga dinilai memenuhi kriteri baik berdasarkan indikator-indikator sebagai berikut, 1) ketepatan penggunaan media, 2) urutan penyampaian materi, 3) efektivitas pencapaian materi, 3) efisiensi penyajian, 4) Kemampuan memotivasi mahasiswa, dan 5) kesesuaian dengan sasaran (mahasiswa).

Kemudian Berdasarkan hasil analisis validitas isi (content validity) dari Aiken's V untuk ahli materi juga menghasilkan nilai diatas 0,5 , maka dari itu seluruh indikator hasil validasi Aiken's V ahli materi juga memiliki nilai validitas yang memadai.

Selanjutnya hasil uji kelayakan produk media komik digital yang diujikan kepada mahasiswa jurusan Pendidikan Vokasional Konstruksi Bangunan yang berjumlah 33 mahasiswa. "Pengembangan Media pembelajaran dalam bentuk komik digital. Hasil dari penilaian berupa instrument angket tersebut bertujuan untuk mengidentifikasi kebutuhan mahasiswa dalam pembuatan media komik digital. Dari 
15 pertanyaan pada instrument angket hampir secara keseluruhan mahasiswa menjawab "setuju" dengan skor (4) dan "sangat setuju" dengan skor (5). Adapun rata-rata dari ke-15 indikator angket tersebut terdapat enam pengukur instrument yang memiliki skor rata-rata tinggi 4,61 dan 4,64 tentang 1) penyajian materi yang sederhana, 2) alur cerita yang disajikan menarik, 3) komik menggunakan tampilan yang menarik, 4) teks mudah dibaca, 5) ilustrasi dalam komik menarik, dan 6) media komik digital dapat meningkatkan motivasi belajar mahasiswa. Sehingga pada hasil akhir diperoleh hasil uji coba produk dari keseluruhan nilai angket mahasiswa adalah sebagai berikut:

Tabel 2. Hasil Uji Coba Produk

\begin{tabular}{ccc}
\hline $\begin{array}{c}\text { Penguji } \\
\text { Coba }\end{array}$ & Presentase & Kategori \\
\hline Mahasiswa $/ \mathrm{i}$ & $90,55 \%$ & Sangat Baik \\
\hline
\end{tabular}

Dari hasil penilaian kelayakan produk yang sudah dinilai oleh 33 mahasiswa jurusan Pendidikan Vokasional Konstruksi Bangunan, berdasarkan 15 indikator tersebut maka dirata-rata akhir hasil uji coba produk dinilai dengan jumlah persentase $91 \%$ masuk dalam katagori "sangat baik" yang terdapat pada table diatas. Maka, produk media komik digital tersebut dinilai sangat baik menjadi media tambahan dalam pembelajaran materi perkuliahan konstruksi bangunan.

Selanjutnya, produk berupa media komik digital divalidasi oleh ahli media dan materi. Pada media komik digital yang berisikan gambar serta percakapan antar tokoh yang menjelaskan materi konstruksi bangunan sebagai media untuk pertemuan materi perkuliahan di awal hingga ujian tengah semester. Sehingga, sangat dibutuhkan penilaian atau validasi terlebih dahulu terhadap media pembelajaran komik digital untuk menentukan layak tidaknya media flashcard ini digunakan dalam pembelajaran mata kuliah konstruksi bangun.
Tabel 3. Data Hasil Validator Ahli Materi dan Media

\begin{tabular}{cccc}
\hline No & Validator & Persentase & Kategori \\
\hline 1 & Ahli Materi & $73,33 \%$ & Baik \\
\hline 2 & Ahli Media & $91,33 \%$ & Sangat Baik \\
\hline \multicolumn{2}{c}{ Rata-rata } & $\mathbf{8 2 , 3 3 \%}$ & Sangat Baik \\
\hline
\end{tabular}

(Sumber: hasil validator ahli materi dan media)

Hasil Validasi produk media pembelajaran berbasis komik yang dikembangkan diperoleh skor rata-rata 82,33\% sehingga termasuk dalam kategori Sangat Baik. Oleh karena itu produk dapat dikatakan layak untuk digunakan.

Pengembangan media pembelajaran pada mata kuliah konstruksi bangun ini didesain dan diproduksi menjadi sebuah produk berupa media komik digital, tujuannya untuk memudahkan peserta didik (mahasiswa) dalam memahami materi konstruksi bangun I. Pada penggunaan media komik digital ini dosen menjadi fasilitator dalam pembelajaran sedangkan mahasiswa berperan aktif dalam pembelajaran melalui diskusi.

Berdasarkan hasil penelitian di atas, media pembelajaran komik digital pada mata kuliah teknologi beton digunakan sebagai variasi media pembelajaran selain slide presentation yang biasanya digunakan oleh dosen dalam dalam pembelajaran untuk mahasiswa program studi Pendidikan Teknik Bangunan Tahapan pengembangan media komik digital ini melalui tahapan proses mencari potensi dan masalah melalui analisis kebutuhan, setelah itu pengumpulan data yang berasal dari responden dan sampai pada tahap desain produk.

Pada tahap desain produk, dibutuhkan kreativitas serta pemahaman yang baik terhadap materi yang akan disampaikan pada media komik digital Selanjutnya tahap validasi desain, validasi dilakukan atau dinilai oleh ahli materi serta media yang sesuai dibidangnya. Terdapat beberapa saran terhadap media komik digital ini untuk dilakukan revisi desain 
sesuai dengan saran yang diberikan oleh ahli media ataupun oleh ahli materi. Sesuai dengan hasil analisis kebutuhan yang menunjukkan bahwa media komik digital mampu menjadi daya tarik dalam media pembelajaran rupanya benar adanya sesuai dengan respon mahasiswa ketika diberikan komik digital ini. Dengan adanya media pembelajaran komik digital ini memberikan variasi dalam belajar sesuai dengan apa yang diharapkan responden ketika analisis kebutuhan diawal penelitian. Media pembelajaran berupa komik digital ini memiliki fungsi sebagai media pembelajaran yang dapat memberikan kemudahan dalam proses pembelajaran serta sebagai variasi media pembelajaran agar peserta didik (mahasiswa) tidak mudah bosan saat memahami materi yang disampaikan oleh pendidik (dosen).

Metode yang dipilih pada penggunaan media komik digital ini adalah menggunakan metode diskusi. Setelah membaca materi sesuai dengan bab pada komik digital tersebut mahasiswa mendiskusikan dengan teman atau pun kelompok. Adapun materi yang disampaikan pada media komik digital ini merupakan materi awal pertemuan sampai dengan ujian akhir semester. Komik dapat diakses pada webtoon yang dapat diunduh diplaystore atau bisa mengakses pada browser www.linewebtoon.com

\section{Kesimpulan}

Dari hasil analisis dan pembahasan pada penelitian ini maka diperoleh simpulan penelitian berupa;

Produk yang dihasilkan media komik berupa web komik yang terbagi kedalam 47 episode dan produk komik dapat diakses https://m.webtoons.com. Hasil penilaian berupa desain produk komik digital berjumlah $90 \%$ yang dinilai sangat baik. Adapun jumlah rata-rata akhir aspek dan indikator karakteristik media pembelajaran berjumlah $91,3 \%$ (91\%), yang masuk pada klasifikasi sangat baik atau layak dan tidak perlu direvisi. Selanjutnya untuk materi yang disajikan dalam media komik digital dinilai 'baik' terlihat hasil akhir antara aspek materi dan media memiliki hasil akhir 73\% yang mana masuk pada klasifikasi "baik". Dari hasil penilaian kelayakan produk yang sudah dinilai oleh 20 mahasiswa jurusan Teknik Bangunan, berdasarkan 15 indikator tersebut maka dirata-rata akhir hasil uji coba produk dinilai dengan jumlah persentase $91 \%$ masuk dalam katagori "sangat baik". Maka, produk media komik digital tersebut dinilai sangat baik menjadi media tambahan dalam pembelajaran materi perkuliahan konstruksi bangun.

Untuk memutuskan media komik digital ini layak digunakan sebagai media pembelajaran mata kuliah konstruksi bangunan I maka dibutuhkan kelayakan uji materi dan media. Hasil validasi materi dan medi pada produk komik digital yang dikembangkan diperoleh skor rata-rata $82,33 \%$ sehingga termasuk dalam kategori Sangat Baik. Oleh karena itu produk dapat dikatakan layak untuk digunakan.

\section{Implikasi}

Pada penelitian dan pengembangan media komik digital ini mempunyai beberapa implikasi diantaranya:

1. Media pembelajaran komik digital ini dapat digunakan pada mata kuliah konstruksi bangunan I.

2. Media komik digital ini dapat dilaksanakan dan dilanjutkan pada tahap uji coba produk sebagai media pembelajaran konstruksi bangunan I.

\section{Saran}

$\begin{array}{rrrr}\text { Adapun } & \text { saran } & \text { yang perlu } \\ \text { dideskripsikan } & \text { pada } & \text { penelitian }\end{array}$ 
pengembangan produk pendidikan dan pembelajaran antara lain:

1. Diharapkan dalam kegiatan belajar mengajar ini mahasiswa dapat berperan aktif dan semakin bersemangat dalam materi kuliah konstruksi bangunan I sehingga dapat meningkatkan hasil belajar.

2. Dalam penelitian pengembangan suatu produk diharapkan mampu membuat produk sesuai dengan kebutuhan dalam dunia pendidikan.

3. Untuk mengembangkan suatu produk diharapkan mampu memahami potensi dan masalah serta mampu mengembangkan ide yang lebih kreatif.

\section{Daftar Pustaka}

Arsyad, Azhar. 2011. Media Pembelajaran. Jakarta: Rajawali Pers.

Listiyani, Mei, I., \& Widayati, A. (2012). Pengembangan Komik sebagai media Pembelajaran Akuntansi pada Kompetensi Dasar Persamaan Dasar Akuntansi untuk Siswa SMA Kelas XII. Jurnal Pendidikan Akuntansi Indonesia 10, no. 2.

Marianthi. (2015). From Digitised Comic Books To Digital Hypermedia Comic Books: Their Use In Education. Piraeus: University Of Piraeus.

Setyorini, Wahyu. (2017). The Effectiveness Of Digital And Printed Comics To Teach Monologue Of Visual And Auditory Students A Case Of The Tenth Year Students Of State Senior High School 1 Ungaran Eej 7 (1) (2017) English Education Journal. Semarang: Universitas Negeri Semarang.

Sudjana, Nana., \& Rivai, A. (2010). Media Pengajaran. Bandung: Sinar Baru Algensindo. 